\title{
PRESIDENT'S REPORT
}

This is my second report as President of the IALL as published during my second election term ending (2016-2019). It covers the period between the Atlanta Conference of October 2017 and the days preceding the Luxemburg Conference of 2018.

\section{THE BOARD}

Since the 2016 International Association of Law Libraries Board Member-election, and from the 2016 Oxford Annual Course onwards till 2019, the Board of the International Association of Law Libraries consists of the following Officers.

- President: Jeroen Vervliet, Peace Palace Library Director.

- Vice-President: Barbara Garavaglia, Director, University of Michigan Law Library.

- Secretary: David Gee, Institute of Advanced Legal Studies, University of London.

- Treasurer: Kurt Carroll, Library of Congress, Washington.

The following Members make up the Board of Directors since the above mentioned elections:

- Daniel Boyer, Nahum Gelber Law Library, McGill University, Montreal.

- Lily Echiverri, University of the Philippines.

- Michel Fraysse, Conservateur en chef - Law Librarian, Université Toulouse 1 Capitole Libraries.

- Ryan Harrington, Librarian, UNCITRAL Law Library, Vienna.

- Kerem Kahvecioglu, Istanbul Bilgi University.

- Petal Kinder, BarNet Jade, Sydney, Australia.

- Gloria Orrego-Hoyos, Law School, Universidad de San Andrés, Buenos Aires.

- Mark Engsberg (ex-officio), MacMillan Law Library, Emory School of Law, Atlanta.

\section{BoArd Meetings}

The Board met on Saturday October 21, 2017 and on Friday October 27, 2017 in Atlanta, where annually returning items were discussed, as well as strategic issues, such as transparency regarding the selection of the venues for future annual courses, bursaries, and scholarships to help defray the cost of visas for attending IALL conferences. Other business included: discussion of the future of Pre-Conference Workshops and the conference Optional Day, and workshops held within IALL's conference framework.

\section{The Annual General Meeting in 2017}

The Annual General Meeting was held on Wednesday October 25, 2017. Scholarship and bursary recipients were announced. Regular reporting took place. IALL also used the AGM as an opportunity to demonstrate its gratitude to IALL's sponsors.

\section{REPRESENTATION}

I accepted an invitation to attend the American Association of Law Libraries (AALL) annual conference in Baltimore in July 2018, where I spoke briefly about the International Association of Law Libraries, and encouraged registration for the 2018 IALL Annual Course. I had opportunities to promote the IALL conference at the AALL general meeting and at the "International Attendees Joint Reception." I have also pursued opportunities to attract 
and secure even more vendor sponsorship for future annual courses of the International Association of Law Libraries.

\section{IALL's 36th Annual Course in Atlanta, 2017}

The 2017 IALL Annual Course, Civil Rights, Human Rights, and Other Critical Issues in U.S. Law, was held in Atlanta, Georgia, from October 22-25, 2017. There was an Optional Day on Thursday October $26,2017$. It was organized by the Hugh F. MacMillan Law Library at Emory University School of Law, celebrating its centennial anniversary. The Local Planning Committee consisted of Christina Glon (Chair), Mark Engsberg, Amy Flick, Avery Le, and Jason LeMay. The Board Liaison was Kurt Carroll. Topics addressed included: from AIDS to Zika: access to healthcare as a human right; information literacy in a fake news world; international terrorism; global and local challenges to refugee protection; the rise and fall of Jim Crow: civil rights' struggles in the American south; and profit-seeking courts and the criminalization of poverty.

\section{IALL's 37th AnNual Course in LuXembourg, 2018}

In cooperation with the Max Planck Institute for International, European, and Regulatory Procedural Law in Luxembourg, and its Library Director, Juja Chakarova, and with the support of the European Court of Justice, and the Bibliothèque Nationale de Luxembourg, the International Association of Law Libraries organized its Annual Course on "Law in Luxembourg - Where Local Tradition Meets European and International Innovation" from Sunday September 30-Wednesday October 3, 2018. The Board Liaison was Michel Fraysse. The Chair of the Local Planning Committee was Martina Winkel. She was assisted by Irina Kühn, Sabrina Logrillo, Allan Mulondo, and Roger Yerburgh.

Jeroen Vervliet IALL President 